\title{
THE PRIORITY OF READERS AMONG MEANINGS AND METHODS IN NEW TESTAMENT INTERPRETATION ${ }^{1}$
}

\author{
Jeremy Punt \\ Departement of Old and New Testament \\ Stellenbosch University
}

\begin{abstract}
Amidst the proliferation of methods in New Testament interpretive practices, the quest for the meaning of texts has only increased even though the elusive nature of textual meaning is more readily admitted and although the once-dominant position of meaning as "textual property" receives increasingly less acceptance. Moving away from the notion of texts as reservoirs of meaning, and alert to the dynamics of the reading process as well as the influence of social location on the readings produced, attention has turned sharply to the role of readers in the reading process. It is argued that, alongside the sharpening of methodological approaches and techniques which shows no signs of abating, the influence of readers and their social locations deserve more attention in biblical hermeneutics.
\end{abstract}

\section{Introduction: Book, Method, Reader}

The Bible, surely no less than other "classics", has always been involved in the human quest for understanding, with human beings since early times often trying to understand themselves, other people, life and reality, both seen and unseen, with reference to these texts. And like other classics, the biblical texts have generally been considered valuable beyond the contextual interests specific to their origin, and worthy of reading and study beyond the meaning consciously or otherwise intended by their authors ${ }^{2}$ (Powell, cf Pike 2003:39). In the academy and to a lesser extent in the church, various methods and strategies have been employed for many centuries to determine the meaning of the biblical texts, with an exponential increase in methodology since the second half of the previous century.

The explosion in methodology, methodolomania, has not done the profession or guild of biblical scholars only good, and few are willing to accept that all that is found in biblical hermeneutics are on par. ${ }^{3}$ Since these matters were argued elsewhere (Punt 1998a; 1998b), this paper argues a simple yet often neglected or discounted point, viz. the acknowledgement as well as the importance of the role of the reader in biblical interpretation. ${ }^{4}$ Indeed, the relative unimportance or at least irrelevance of critical methods for appropriating the biblical texts and their meanings is perhaps nowhere as clear as in the general usage of the Bible by various readers, for various purposes: informational, devotional, historical, dogmatically, missionary/ evangelistic, and so on. Readers engage the Bible and generally find it a positive experience,

1. Paper read at the SBL International Meeting held in Cambridge, UK, 20-25 July 2003.

2. Claims about the divine authorship or authority of the Bible as the Word of God, have in the past often proved to be constitutive of, or influential in, theological claims regarding the inerrancy and infallibility of the Bible. Similar, theological, arguments are at times still mounted in defense of authorial intention.

3. Literary criticism in general is often, notwithstanding its positive contributions, accused of, e.g. being "alienating, jargon-ridden, authoritarian, and repressive" (Winter 1995:546).

4. The reader in a broad sense, that is, in the three publics identified by Tracy as society, church and academy, and trained, professional readers as well as readers in general. 
notwithstanding the accusations leveled by trained or academic readers that such interaction is characterised by uncritical, self-affirming, and otherwise inappropriate positions and results.

As much as academics might think that they can or should direct the interpretation of the Bible, or in some extreme cases even may argue that they possess the true meaning of the ancient texts, the academy is in fact not very influential in determining how people read the Bible (cf Clines 1997:11), whether in church or in society at large. This has, however, not significantly deterred many biblical scholars from attempting the impossible, that is, to fix the meaning of texts, whether through appeals to authorial intention, formalist and rhetorical structures in texts, socio-historical contexts, or various other methods. My argument should not, however, be taken as one against the use of methods in general, or a particular methodological approach in particular ${ }^{5}$ - the many different hermeneutical positions employed in the past and present towards the meaning of biblical texts have arguably all advanced our understanding of the richness of these texts. ${ }^{6}$

In fact, methodology of some or other kind will on the one hand always be part of systematic academic work, and therefore exert - varying degrees of - influence on biblical interpretation and the meaning of texts, in the academy but generally also elsewhere. The emphasis on methodology may not, however, on the other hand be allowed to obscure the considerable, and often determinative, influence of the real reader on the meaning of the text. And while my paper focuses on the academy and its readers, other readers of the Bible in broader society, and their contributions in making sense of the text, cannot be ignored or slighted. Whether or not an appeal to the biblical nature of reader-response theory is appropriate or justified ${ }^{7}$ (Pike 2003:37), the focus on the real reader and adequate attention for his/er identity and social location has become considerably sharper over the last decade or so. The reasons for discovering the role of the reader are manifold, but in part, it is increasingly recognised that the reader plays a decisive role in making meaning of texts.

\section{The Quest for the Meaning of the Text ${ }^{8}$}

The intensity of the quest for meaning has not diminished over the course of many years, with some scholars talking of a "battle" over the word meaning (e.g. Poirier 2000:250). In modern times and in particular since the advent of historical-critical approaches in biblical studies, the common assumption in both professional and popular circles was that a text has a single or

5. Not even as far as reader-based or -oriented approaches are concerned. This in part a practical consideration given the wide (some might say, confusing) array of possibilities in method as well as methodology; cf e g Winter (1995:529-549).

6. Including all who engages with the Bible as readers, regardless of their context, I would therefore be hesitant to subscribe too readily to Steiner's distinction between reader as servant and shepherd of the text, and critic as judge and master of it, functioning at a distance (Vanhoozer 1995:315).

7. Pike's concern is really "with the development of spiritual literacy rather than inculcation in the methods of historical or literary criticism" (Pike 2003:47); i e, his concern for the reader is overshadowed by his spiritual, dogmatic framework. E g, "The teacher who teaches the Bible biblically must move children from personal interpretation to consider authorial intention in the context of the larger Bible story of redemption through Christ" (Pike 2003:48); and "The most important prerequisite for a biblical reading of the Bible is, undoubtedly, a relationship with Christ ... a spiritual transaction between the reader and divine author" (Pike 2003:49).

8. The overriding concern in biblical studies globally is rather with issues of power and ideology in the interpretive process, than with the meaning of texts. However, in the South African context issues around textual meaning are still prioritised and merit a fuller discussion, and should not be construed as an implicit inclination on my part towards this ranking of concerns! The aim here is not to provide a full discussion on or definition of meaning; for one example of such an account cf Schneiders (1991:14-17; 161-164); the debates about indeterminate meaning, underdetermined meaning, and others, are not engaged in this paper. 
basic meaning - a position still held by some biblical scholars, and a significant number of Bible-readers today. Earlier, the ecclesial contexts of interpretation provided the necessary regulative controls for the interpretation of texts. However, with the multiplying of interpretive contexts and locations, the meaning of the text - as elucidated by the academy and/or its tools (Barr 1995:2-4) - became the new measure of control in interpretation. In the view of Fowl and Jones (1991:6-8) this moreover initiated a quest for method centered on equipping the "isolated, autonomous individual" to discover the meaning of a text, regardless of its eventual use.

Others, however, (e g Fowl 1990:379-398, taking his cue from Jeffrey Stout) propose that the search for meaning, and in fact the very notion of textual meaning, be eliminated. This is necessitated by the difficulty and deadlock in discussions that result from the anticipation of textual meaning to the detriment of being able to use the text, as well as the problem of ascribing the word meaning to one particular use of the text only, generally the author's intention. In formal debates on meaning, it is claimed, no consensus exists on what the term meaning refers to and the term only leads to confusion. Fowl therefore contends that the phrase "interpretive interests" comes much closer to describing the result of readers' or interpreters' interaction with a text. ${ }^{10}$ When one disavows the notion of meaning it does not resolve (or dissolve?) interpretive disagreements but provides a way of addressing the disagreements which for Fowl (1990:385-388) are found especially on three levels: the formulation of one's interpretive interests; interpretive practices; and, the choice of interpretive method. ${ }^{11}$

Fowl's remarks are helpful in showing the broad range of activity in which - academic interpreters indulge in, and the need to distinguish different elements when talking about the meaning of texts. His views are also helpful in countering remnants of archeological or excavative notions of textual meaning, i.e. that meaning is a "property" of the text (Fowl 1995:16). "For many interpreters ... the encounter with the text is essentially a one-way conversation. That is to say, the meaning of the text is fixed, unchanging" (Pregeant 1995:542) ${ }^{12}$ Whether Fowl's proposal to exchange the debate about meaning for one about "interpretive interests" will result in less confusion is, however, doubtful, as the range of "interpretive interests" remains as broad - and maybe as vague - as positions on the "meaning" of texts. Perhaps the elusiveness of the definition of meaning is not so much the point of Fowl's argument as is his reluctance, shared by others, to accord texts too central a role in the interpretive process. ${ }^{13}$ And what Fowl's argument perhaps shows best, is the continuing, strained relationship between texts and readers.

9. And so the continuing but less than constructive debate between church and academy on biblical meaning ensued (cf Barr 1995:2-4), and also contributed to the the situation where "interesting (detached) readings" can be distinguished from "interested (committed) readings" (West 1991:33-34; cf Draper 1991:237).

10. Cf also Fowl (1991:15;26 n30) and his references to Brett (1990:357-377). Elsewhere Fowl, with Jones, refers to the "illusory quest for the meaning of a text" (Fowl and Jones 1991:15).

11. The latter can be guided by three choices: a pluralist option ("the maintenance of plurality as a worthy end in itself"); a social responsibility choice (relying on notions of social justice and well-being, which again presupposes a general subscribing to a "supercommunity" as well as "ahistorical transcultural" virtues e.g. justice); or, a communal or collective position ("a specified telos to which the life and practices" of a particular historical community is directed) (Fowl 1990:389-396).

12. Still a fairly pervasive notion of the locus of meaning, cf e.g. Pregeant (1995:541-545).

13. Cf also a later essay by Fowl where he argues against the notion that ideologies are characteristics or properties of texts (1995:15-34). To the contrary, cf Clines (1993:84) on ideologies "inscribed in" texts. Neopragmatist Richard Rorty further challenges the idea that texts have "natures", insisting they have "uses" only (Vanhoozer 1995:311). 
The postmodern turn in biblical hermeneutics is often, depending on one's stance, praised or blamed for disconnecting meaning from texts. The anti-foundationalist stand of postmodern biblical criticism is at times demonstrated through the example of deconstruction where the notion of "meaning as textual property" is radically challenged. "[M]eaning - to the extent that there is such a thing - does not inhere in a text any more than it might inhere in a dream ... Meaning is what we make of texts, not an ingredient in texts" (Adam 1995:33). This sentiment is strongly shared by The Bible and Culture Collective (1995:20-69), who then also castigate biblical scholars for claiming to practice reader-response criticism but only go halfway in that the reader-text dichotomy is retained intact, and the text is still believed to provide the necessary "guidance" to its readers.

\section{Farewell to Innocent Texts, and Readers!}

The critique and complete collapse of "the modernist construct of the ideal observer and narrator" ${ }^{\prime 14}$ (Segovia 2000a:175) has put the reigning master paradigm of interpretive neutrality and hermeneutic objectivity under serious constraint.

[A] historical experience and cultural reality as particularised and contexualized as any other is bracketed and universalized as normative human experience and reality - the reality and experience of center - with the rest unable to transcend their social locations - the realities and experiences of the margins (Segovia 2000a:173).

Apart from the issues around power in interpretation, this amounts to an "innocence syndrome" and is continuously exposed as feigned and dangerous innocence. Feigned, on the one hand, because of the increasing acknowledgement of the situatedness of human beings, providing the context from where and through which human existence for the individual and/or groups involved, are filtered and thus defined. Dangerous, on the other hand, because "the myth of innocence is in itself a highly political ${ }^{15}$ agenda" (Segovia 2000a:173), with the peril only intensified by attempts to disguise and sublimate it.

The danger goes beyond feigned innocence and its accompanying dangers, because the unique is first generalised, and then made normative. This is probably most powerfully illustrated in the historical-critical approach of Western scholars, claimed but often simply assumed to be developed and practiced by partial and objective observers, while in fact amounting to no more than a construct of the scholars themselves. The overarching construct of a universal and disinterested gaze in the end becomes a normative gaze imposed on others, and serves as the measure against which all others are evaluated (Segovia 2000a:17). Given its claims to objectivity, neutrality and universality, the historical-critical paradigm did not allow room for a reader to contribute to meaning; to the contrary, with readers standing aloof from the process, their task was to find or locate the meaning already present and waiting to be discovered.

The real reader was unfortunately not much better off in the literary-critical approaches which developed alongside the array of historical critical methodologies. In fact, while literary critics had the text as their point of departure and employed a range of literary methods to provide the meaning of the text through focussing on its conventions, formal features, and other processes by which it conveys sense, they often shared the philosophical or epistemological underpinnings of their historical-critical colleagues. The quest for objective

14. It is being replaced by the alternative, postmodernist construct of a narrator and observer who is always situated and engaged (Segovia 2000a:175).

15. The post-Enlightenment historical -and literary critical reader assumes a disinterested, objective, and also apolitical stance, all of which is a myth (Vanhoozer 1995:312). 
knowledge is still dominant and shrouded in claims of the scientific nature of the endeavours (Vanhoozer 1995:312-313; cf Segovia 2000b:61-64).

However, amidst, among others, the resistance against structuralist discourse, its implicit impersonal nature and the eclipse of the role of the reader in making meaning, the real readers were discovered anew with "a return to the recognition that readers are people with all properties that go with being human: gender, history, politics, and beliefs" (Winter 1995:529).

The current appeal to recognise readers and their role in making meaning goes well beyond the discovery of the often idealised reader in the text, since the emphasis is now on real, flesh-and-blood readers. Conceptualising the reader as a semantic or semiotic position generated by the text serves a valuable purpose in identifying the ideal reader, in order to allow for the framing ${ }^{16}$ of the text, an enlarging and augmenting of the text. However, it is not only important but also increasingly inevitable to deal with particular, real-life, flesh-andblood readers within and as constitutive of their social contexts. Moving beyond readers as literary constructs, real readers can be taken into consideration, and their influence on meaning, the way they shape and determine readings in a variety of contexts: ecclesial settings and faith communities (clergy, etc), in scholarly and academic circles (reference works; commentaries; etc), in society in general and the media in particular (letters to magazines and newspapers; popular books; etc), and so on. Attention for the real reader does imply that the point of departure shifts from text to reader, but it does not necessarily follow that the text should be disregarded or even discarded as indeed some radical reader-response critics argue. ${ }^{17}$

By now it is probably clear that mine is not an attempt to invoke the ongoing debate about the locus of meaning; suffice it to say that I subscribe to the view that meaning is generated (yes, not existing as such somewhere!) in the interaction between reader and text (yes, the reader is not alone in his/er constructive efforts but interacts with the text). ${ }^{18}$ My approach is therefore dualist, avoiding the monistic position which holds that the reader, or text, is fully responsible for the meaning of the text. In a dualist approach, power is divided between reader and text, and the independent existence of either of the two in the reading process can be resisted. ${ }^{19}$ The notion of interpretation being akin to that of a conversation as suggested by Gadamer, Tracy and others, in my opinion, still make the most sense and disallows a hostile takeover of textual meaning and significance by either an appeal to original meaning or the contemporary context (Levison and Pope-Levinson 1995:329-330). Nevertheless, the focus has shifted irreversibly to the reader as point of orientation.

16. Cf recently Bohnen (2000:75). Reading as framing is perceived as a reader's application of an interpretive procedure through construing an intertextual relationship between two or more texts, a "host text" and another (or more) "guest text" or intertext (Bohnen 2000:75).

17. See further my argument below.

18. When pushed for a definition of reading, can one offer much else than Wolfgang Iser's well-known remark that it is a process of responding to black marks on a page? (e.g. Winter 1995:529).

19. Louise Rosenblatt describes reading as a transaction between text and reader, exchanging the notion of the meeting of two "self-contained" and "already defined entities" for one where two entities are transformed through their engagement with one another (Winter 1995:539). Such an approach has more integrity and seems also more fruitful than the pragmatic fatalism espoused by Vanhoozer (1995:235), saying metaphorically, "One can do many things with water from a well; but in the desert of criticsm, a drink should be received with eagerness and thanks". 


\section{A Reader-oriented Approach ${ }^{20}$}

What happens when the debate about the priority of text versus reader, authorial intent versus reader reception/response is not approached from a theoretical perspective, delving into literary theory and deductively make claims for how readers do and should react to texts? Put differently, the important starting point for the debate about readers and their involvement with texts have to be not a constructed ideal reader, but a perceived real reader. ${ }^{21}$ New Testament scholarship at times and certainly not only in South Africa operates within a positivist-objective paradigm (Vorster 1988:31-48). In this framework a method is assumed to be neutral, disinterested and scientific, as found in the following statement: "a systematic procedure that may be applied to a text to determine its meaning, in such a way that different readers using the same method will arrive at similar interpretations" ${ }^{\text {"22 }}$ (Hays 1989:224 n24).

However, such an acclaimed and often staunchly defended neutral position on interpretation is increasingly questioned, in South Africa in particular, given a legacy of abuse of Scripture for all kinds of political and quasi-political purposes. Whenever one argues for replacing the rigid and controlling positivist paradigm with a contextual and relativist approach to reading, the question, however, crops up whether or not one form of hermeneutical coercion is replaced by another: objectivism versus relativism or subjectivism (cf argument below). More pointedly, the opinion is often mooted - perhaps not always out aloud in learned company - that with a positivist-objective reading at least results were produced, the goods were delivered, as it were. It is implied that with the reader-oriented reading strategies very little remains of textual meaning, and at times, even of the text.

\subsection{The Reader: Biased and Situated}

The "world in front of the text" or Lategan's third pendular movement (1994:1-17) emphasises the role that readers play in the interpretive process. Although it has always been taken for granted that readers are a constituent element of the textual communication process, ${ }^{23}$ the emphasis now shifts away from the reader as neutral, impartial, autonomous and individual subject encountering the objective meaning of the textual object, that is a "stable text with determinate meanings" (The Bible and Culture Collective 1995:39; Harrisville 1995:211). Readers are influenced by their cultures, ideologies, and experience of life in general, and thus interpret the same text differently. It is realised that readers are as much read by the text as they themselves read the text. These realisations are turning into an acknowledgement of the reader's contribution made throughout the interpretive process.

A reader-oriented approach does not deny other important aspects in the communication process or disallow them to surface, but recognises that the whole communication process exists because of the presence of the reader and the reader's interests in using a text for his/er purposes. And this of course calls attention to the issue of ideology: a reader is not a tabula rasa, an island on his/er own as our increasingly individualist society would often lead us to believe. It must therefore be taken for granted that a reader is influenced by normal societal

20. As opposed to a "reader-centred" approach. Cf Noble (1994) and Thiselton (1992:515-555).

21. Cf e g Vanhoozer (1995) who, in his essay on the reader and the text, presupposes a level playing field, where all texts, readers and their locations are much of a muchness and where differences may be real but are nevertheless very much on par.

22. The positivist and assumed objectivity of the definition is clear: the ideology and assumptions, the location and social position, the purpose and aim, etc. of the reader are sidelined. Furthermore, the implication is that a method is also contextless and neutral, capable of always delivering the same if used in an analogous way regardless of different contexts, different people applying the method, and so on!

23. Cf e g Petersen's communicative model (1978: esp 33-37) based on Jakobson's theory. 
concerns, be it economically, politically, religiously, socio-culturally or whatever combination thereof. ${ }^{24}$ The reader cannot distanciate him/herself from these concerns in the sense of suspending them, although a relativisation of these concerns would happen by way of their acknowledgement and entering into a critical dialogue with them. ${ }^{25}$ The particular ideology(ies) present in a reader, with which the reader interacts consciously or otherwise, is not always equally consciously perceived or admitted by the reader involved, and in fact, at times even denied. $^{26}$

But going beyond ideology, which for some may call up ethereal notions, readers are socially located or situated. A radical reader-oriented approach found most sharply in Fish's notion of the interpretative community, which in reality determines the meaning of the text eventually replacing the text - has been taken on in varying degrees by some biblical scholars. Stephen Fowl's approach, for example, explores the notion that meaning resides in interpretative communities, and their traditions or histories of interpretation (Fowl 1995:399-403) in particular. However, while such an approach shows upon the importance of the social location of the reader, it can nevertheless happen that the interpretative community stays largely virtual constructed through a history of ideas-approach, rather than through the materiality of social locations.

This failure to accept, and at times the denial of, the reader's interest(s) in texts worsens the situation by prolonging the false image of a text having but one meaning, locked in a text and to be disclosed by the most objective reader with the ultimate method. ${ }^{27}$ Failing to accept that every reader has a stance, makes conversation about various and diverse readings very difficult, if not impossible.

A reader-oriented approach accepts that all knowledge, all truth and all meaning are reader-mitigated. The often-poignant acceptance of non-objectivism is not secured in denial, neither in relativism, but admits the relativity of human nature. There is no denial of knowledge, truth and meaning, as it is accepted that the reader him/herself is the subjective bridge to this. The underlying assumption is naturally that there is "something out there", that it is indeed possible to speak of and relate to reality. ${ }^{28} \mathrm{~A}$ reader-oriented strategy need not be radical or maximalist in the sense of perceiving meaning as consisting of "the reader's response" 29 only, of seeing meaning to be completely the reader's construct, with the text, at the most, functioning as "pretext".30

24. Vanhoozer dismisses the value of ideological readings all too glibly when he claims that "ideological readers try to make the text conform to their devices and desires" (1995:313); ideological criticism concerns far more than reconstructive readings, and no-one can escape the influence of ideology (at least not in the Mannheim if then Marxist sense!).

25. Cf Fowl (1995:15-34) who claims it impossible for texts to have ideologies, since ideologies are the attributes of the readers of the texts.

26. Again, in a logical-positivist setting, any acknowledgement of subjective concerns mitigates against the ideal of the real truth, or the ultimate meaning of (in this case) a text.

27. Even the very worthwhile acceptance of the multivalency of texts does not constitute an acceptance of the reader's interestedness, as in this case the text is still responsible for providing these possible readings.

28. Cf the criticism levelled by The Bible and Culture Collective (1995:62, quoting O'Leary) at the caricatures made of Derrida's views and deconstruction: "Derrida is acclaimed as a nihilist, abolishing the extra-linguist referent of language, and an anarchist, replacing meaning with pure randomness of the freeplay of signifiers without signification, signifiers whose meaning is merely their absolute negative reference to other signifiers." The Bible and Culture Collective contends that when reader-response critics collapse the reader-text/subjectobject dichotomy, they are acting in way similiar to deconstructionists except that the latter operates on a broader level. Cf also Winter (1995).

29. E.g. "The reader's response is not to the meaning; it is the meaning" (Fish, quoted in Thiselton 1992:539).

30. Not an intertextual pre-text, but pretext as excuse, as subterfuge. 


\subsection{Reader-orientated Methods}

As claimed above, the realisation that meaning is not something found locked away within a text that only needs the right interpretive key to emerge as a valid, true, objective and valuefree product, brings the reader into focus. In fact, it follows that when readers assume the primary responsibility for making meaning, the priority shifts to readers and their experience(s) of reading.

Meaning is not in the past (when the text was produced) nor in the text as object, but meaning is produced in the reader's present when the text is read (The Bible and Culture Collective 1995:25;42, the latter with reference to Murfin).

The Bible and Culture Collective (1995:24) leaning on Mailloux's earlier work, attempts to account for Reader-Response criticism as methodology by construing a threefold taxonomy of readerly approaches: psychological or subjective; interactive or phenomenological; and, social or structural. Each of these approaches departs from a specific position and is further guided by that position regarding other "major theoretical questions".

The psychological or subjective approach chooses to see reading as primarily an individual and not social experience - and thus accepts that the reader and not the text dominates in the reading process; and ultimately chooses in favour of seeing the reader as an ordinary rather than expert reader. The interactive or phenomenological approach views the interactiveness or reciprocal relationship between text and reader as central. This approach holds the reader sometimes as an expert and sometimes as an ordinary reader, and is least interested in whether the reading process is an individual or social affair, choosing more often the former. The social or structural approach emphasises the "social location and conventions" within the process of reading (as opposed to matters of the individual reader), with little interest for the interactiveness or not of the reading process, and also holds the reader to be sometimes an expert and sometimes an ordinary reader.

Be that as it may, two broad-ranging critiques are often registered with regard to readeroriented methods in biblical studies. A criticism often leveled at many of the reader-oriented approaches to texts, is that they tend to remain text-oriented in that the text still retains an objective status. The "implied reader" (Iser), "ideal reader" (Powell), and many other fictive (i.e. textual) readers ${ }^{31}$, the interpretive gaps and so forth are still provided - described and defined - by the text. The Bible and Culture Collective (1995:44) therefore denies any claims that reader-oriented approaches - at least in the sense of "a radical reader-response criticism invading biblical studies" - are taking over the scene of biblical interpretation. Indeed, a serious complaint lodged with regard to Reader-Response criticism is that biblical studies has not yet begun to attend seriously to the reception history of biblical texts. As long as biblical reader-response critics concentrate on the implied reader and narratee in the biblical texts, they will continue to neglect the reception of biblical texts by flesh-and-blood readers" ${ }^{32}$ (The Bible and Culture Collective 1995:36, their emphasis).

The reason provided by Moore (1989:105-106) for the perceived unwillingness of biblical scholars to read the biblical texts as real readers, is their fear of the individualistic or

31. Long lists a whole range of "readers" which scholars have claimed as derivatives from the text, literary products in a sense: informed reader (Fish); mock reader (Booth); competent reader (Culler); model reader (Eco); average and super readers (Riffaterre); strong, or mistaken/mistaking reader (Bloom); deconstructing reader (Derrida); perverse reader (Barthes); feasting reader (Hartman); subjective reader (Bleich); transactive reader (Holland); validating reader (Hirsch); amazing/a-mazing reader (Roger); resisting reader (Fetterley); and so forth (1994: 402-404).

32. Moore (1989) and others have the same complaint. Cf the recent attempt by TMS Long in South Africa, reading Revelation as such a real, flesh-and-blood reader (1994:395-411) by using David Bleich's concept of dialogue. 
subjective nature of the actual reader. Moore therefore contends that the real readers of the Bible are "repressed readers". Moore has however been criticised for his inability to progress beyond pointing out the problem with or failure of the "real reader" (Long 1994:401). Temma Berg's views provide an important angle to the debate when she charges the confines of Christian dogmatism with the failure of Reader-Response critics to read the biblical texts as real readers (Berg 1989:187-206). ${ }^{33}$

Another series of complaints from The Bible and Culture Collective (1995:40ff) derives from their contention that biblical reader-response criticism has unreflectively "grafted readerly terminology onto historical-critical scholarship" which had led to "an ideological mutation that is blind to both the oppressive and liberating power of its critical discourses." The argument stems from the fact that biblical reader-response critics share with historicalcritical scholars certain tenets, namely that the text as an object, a "thing-in-itself", is in control of the reading process; that the meaning of the text is prescribed by the text, whether it is meaning as reference ${ }^{34}$ or meaning as event $;^{35}$ positivistic and pluralistic reading practices, which allows various correct meanings but only a certain "determinate core" of meaning; and, the protective boundaries provided by ideologically constituted, scholarly guilds with their theological agendas.

For The Bible and Culture Collective the future of reading lies in taking the collapse of the subject-object or reader-text dichotomy serious, and so shifting the critical attention from the textual object to how readers make meaning within a set of particular reading conventions. Furthermore, once reading practices are viewed as the site of construction of reality and are questioned self-reflexively, then this could open up the question of the ethics and politics that has surfaced so forcefully in other guilds (The Bible and Culture Collective 1995:51-87; emphasis in original).

However, whether the text with its role of providing guidance in the reading process needs to be fully discarded in order both to acknowledge the role of the reader in the production of meaning and to account for the ideological nature of all reading or interpretation, is debatable. ${ }^{36}$ It may be required and in fact be more profitable in the end to reconsider the role of the text in the reading process, but then also the conceptualisation of the text, taking care to move beyond its almost fetishistic objectification.

Still, a real need in reader-oriented approaches to the Bible is the urgent requirement to study the reception of biblical texts by their actual readers, and to do such studies as real readers. The study of the reception of texts could minimize if not obliterate the perceived

33. Long does not follow through either. After identifying the variety of readerly positions (402-404), he fails to actually account for how these positions influence reading, which positions are dominant, what the ideological implications of the choice for a certain position(s) as dominant might be, etc. As, admittedly, a trained theological and academic - reader, he also fails to account for important theological lines (as opposed to other scholarly or academic positions) which might influence his reading.

34. The Bible and Culture Collective (1995:45) contends that the reference is often not to a "real socio-historical referent" but to the "linguistic and imaginative constructs of historical critics", meaning that biblical readerresponse discourse ends up being "self-referential".

35. That is, meaning as significance which in The Bible and Culture Collective's minds recalls the New Hermeneutic's insistence on the text's ability to transform its readers - although the New Hermeneutic held the reader as "the sole authority who could attest to the truth of his or her transformation" (1995:45-47).

36. A good example of how the text is read contra the position by The Bible and Culture Collective, namely in historical-critical fashion and according the text an objective status, while taking the ideological nature of the text as well as the reading of the text in particular social locations into account, can be found in liberationist approaches e.g. Liberation, Feminist and other such theologies. 
"gap" between the ancient text and the (post-)modern world ${ }^{37}$ (Fowl 1995:399-403, cf Adam 1995:20-21). This will provide assistance in the ecclesial and wider societal context to the most important task facing the theologian: How to change, and therefore be contextually relevant, while remaining the same, and therefore continuing to be within the Christian tradition (Villa-Vicencio 1981:15, his emphasis).

In short, the emphasis on the reader and his/her priority amidst the multitude of methodologies is crucial for coming to terms with what texts really mean to real readers today. A vital, but still often missing, element in dealing with real readers is the need to situate them in their equally real contexts, their social locations. Before dealing with this matter, a few words on the question of what is left of the text, and what its place and role could be in a reader-oriented hermeneutic.

\subsection{Any Remaining Role for the 'Text'? ${ }^{38}$ The Text as an Other}

If something remains of the text in reader-oriented hermeneutics, what role is reserved for the text? Do "( $t$ )exts, like dead men and women, have no rights, no aims, no interests"? (Morgan and Barton 1988:7). When interpreters take the intention of the author serious, is it because it is in their interest to do so? Are the textual gaps identified for filling, and the textual constraints pointed out located in readers' minds or communities rather than in texts? Should the much vaunted control exercised by a text over interpretation nor rather be explained according to the interest(s) of the interpreter of the text? And so, to repeat the question: Does any role remain for the text in the process of its reading?

Against reader-oriented positions, the plea for a "realism of reading" seeks to locate meaning as an entity firmly lodged in the text, otherwise, it is claimed, texts cannot "challenge, inform, or transform their readers", and "reading would cease to be a dangerous, world-shattering prospect" (Vanhoozer 1995:317) ${ }^{39}$ The fear is that texts will be abused, and interpretations allowed to run amok under the operative skills of abusive readers if an objective yardstick is not retained, a function typically ascribed to the text. ${ }^{40}$ Realism is believed to ensure that the integrity of the text is safeguarded, and the danger of abusive readings minimised (if not eliminated). Without saying how or by whom this is to be determined, Vanhoozer (1995:325) states, "The reader has a responsibility to receive the text according to its nature and intention". If allowing the text to have its say - being the "prime interpretive interest" - amounts to "to heed and hearken to the text with attention, humility, and respect" (Vanhoozer 1995:318), few readers will probably disagree, but unfortunately these concepts border on being vague.

As much as it is an attempt to protect the text, can the neatly separated categories which the realist approach invokes, be retained today? For example, the claim that "the reader's first reflex should be charitable: Understanding precedes criticism as interpretation precedes use" (Vanhoozer 1995:315), seems to maintain the notions of objectivity, neutrality, and scientific disinterestedness. On the other hand, the danger of abusing and victimising the text, of

37. This positive element to the text's tradition of interpretation is accompanied by an adverse factor, viz that this tradition can become a powerful tool of control over the interpretation of the text; cf Cormie (1991:186ff).

38. Cf Schneiders conscious choice - insistence, rather - in her study on hermeneutical theory not to take "method (the operations of the investigator)" but the "object (that which is to be studied)" as point of departure (1991:24).

39. Cf Vanhoozer (1995) for criticism of The Bible and Culture Collective's view (1995) and his counter-argument in favour of a "conservative" reader-response approach.

40. But given, in particular, the influence of deconstruction as method as well as theory, the stability of the text is eroded and it therefore is unable to serve this role of stable, neutral yardstick. 
engaging in "interpretive violence", of ventriloguising the text is more real than apparent, flowing from the denial of a reservoir of meaning in the text and the affirmation of the reader's constructive role in making meaning. Eco is certainly right when he worries about the impingement on the rights of the text while the focus is on the rights of the reader alone (Vanhoozer 1995:316). How does one arrive at a legitimate interpretive pluralism that excludes a free-for-all, an anything-goes, and rather value the text, its reader and their relationship when they interact, a pluralism which acknowledges the active role of the reader which does not obliterate the text?

The otherness of ancient literary texts is generally admitted, although scholars often explain this otherness differently. ${ }^{41}$ The biblical documents as products conditioned by a particular historical context can naturally be expected to appear other-ly, ${ }^{42}$ but their otherness can also be understood in another way, not as obscurity but as challenge. Avoiding the danger of modeling the Bible to fit the purposes required of it by readers implies that readers allow the Bible to challenge their established sense(s) of identity. Biblical texts can indeed become a challenge to its readers when they are "willing to be interrogated by Scripture in addition to interrogating Scripture" (Fowl and Jones 1991:42-44). ${ }^{43}$

Christian communities must be aware of the possibilities of interpreting Scripture in such a way that it supports rather than subverts corrupt and sinful practices. This means that we Christians will need to learn to read the Scriptures "over-against ourselves" rather than simply "for ourselves" (Fowl and Jones 1991:42).

It is insisted that a proper notion of readings of the texts should include both the readings provided by Christian communities of the Bible, as well as the Bible providing readings of our lives. "[T] community ... Scripture functions as an outsider when it is read 'over-against ourselves",44 (Fowl and Jones (1991:36, 111). And, secondly, an "over-against ourselves" reading requires an ongoing engagement for communities with critical biblical scholarship. Whilst this does not imply that all Christians should become professional biblical scholars, it does mean that Christian communities need to develop and foster relationships with such scholarship. ${ }^{45}$

In the wake of the demise of the historical-critical method, ${ }^{46}$ Segovia (1995b:276-298) has proposed to read the Bible instead with what he calls "intercultural criticism", which has as its

41. E.g. Smit (1998:314) refers to the otherness of the texts in temporal and literary senses, and adds that the otherness of (interpretive) tradition, of other (contemporary) readers, of other contexts, and of the Other speaking in some way through these texts, are also to be respected. Aichele (1993:13), on the other hand, refers to the otherness of the texts in materialist or deconstructive sense.

42. The status of the Bible as a classic in literary and other senses, and the accompanying, bridge-building nature of its interpretive tradition or history (Fowl 1995:401), serve to alleviate much of the apparent strangeness of the Bible - perhaps to the detriment of its interpretation?

43. They provide examples of where, historically, this both did and did not happen: Dietrich Bonhoeffer in Nazi Germany over against the Dutch Reformed Church in Apartheid SA (Fowl and Jones 1991:42; also 96104,135-159).

44. Such notions are voiced in the Bible itself: Deut 31:19,26 emphasises that the Torah becomes "a witness against us", Eph 4:12 stresses with the image of the word of God as two-edged sword, that it is a discerner of the thoughts and intents of the heart (Jeffrey 1996:376).

45. The latter approaches the suggestion by Siker, that in addition to Christian communities reading Scripture "over against" themselves, there is a need to read Scripture against Scripture: Paul against the Pastorals, the Synoptics against John, the prophetic against the priestly literature, and so on (Siker 1993:150-152). For collaboration between "trained" and "ordinary" readers, cf West (1991); criticism in this regard is offered by Segovia (2000b:68-72).

46. Not acknowledged and definitely not celebrated by all, cf e.g. Bray (1996). However, cf e g Segovia (1995b:277-285) for stinging criticism of this method. 
fundamental purpose a reading of the biblical text as "other"47 - not to be overwhelmed or overridden, but acknowledged, respected, and engaged in its very otherness. ${ }^{48}$ It is a strategy that is ultimately grounded in theology of otherness and mixture and a hermeneutic of otherness and engagement ${ }^{49}$ (95:286).

Unlike the historical-critical approach which deliberately ignored the social setting of the critic reading and interpreting biblical texts, intercultural criticism takes the reader serious, not as "unique and independent individual but rather as member of a distinct and identifiable social configuration, as a reader from within a social location". But, not only the reader, but also the text is viewed from a social, temporal and historical perspective - the text is culturally and historically remote:

a literary, rhetorical and ideological product in its own right; an artistic construction with underlying strategic concerns and goals in the light if [sic, read: of] its own point of view, its own vision of the world and reality, within a given historical and cultural matrix (Segovia 1995b:295).

Added to the otherness of the reader and text, the interaction between the text and reader (=reading) should be understood in terms of both construction and engagement. All attempts at reconstructing the text - regardless of how well-informed or self-conscious it may be even as the other, are nothing else but construction. ${ }^{50}$ And, as far as engagement with the text is concerned, perceiving the text as other requires critical engagement with it, with liberation as goal. In addition, engagement with the text as other requires the effort to understand how others have interpreted the text (Segovia 1995b:297-298).

When the debate involves the real readers of the Bible, the academy have to realise its particular role, and to be frank, its relative lack of influence, in making sense of these texts. Academic readers will do well therefore to consider the influence of the status ascribed to the Bible by real readers: canonical, normative, authoritative, a foundational document! Even when granted that it is an accredited status and often accompanied by apologetic concerns, it has to be factored into the reading process, without excluding others that read the Bible for different reasons. Such authority is ascribed to the biblical texts by more than one public: church, society, and even a significant complement of professional scholars. As normative and classic text it is generally not interesting but interested readings taking place, not to pleasure academics, but is about the serious business of readings by and for committed people.

Biblical texts have a role to play, not because they contain meaning in themselves, which lies there waiting to be discovered, but because texts mean insofar as they function intelligibly within specific cultures or subcultures (Meeks 1986:183-184, in reliance on Lindbeck). Indeed, Meeks argues that texts need to be understood, which happens when they are used in an appropriate way. That leads him to conclude that hermeneutics takes place where - and only when - "the text finds a fitting social embodiment".

47. Respect for the otherness of texts is the basis for an ethics of deconstruction, which can be traced to Levinas' insistence that the alterity of an other should be respected and not be made into an object to be mastered by consciousness (Critchley, in Winter 1995:535). Cf from a different, ethics of interpretation-perspective, "To treat a text justly is to respect it for the kind of thing it is, that is, to entertain its perspective and to heed its voice"; and, "The priority of the text means the priority of the voice of the Other, a voice to which we owe an initial courtesy and respect" (Vanhoozer 1995:315, 326).

48. The otherness of the text is often acknowledged as a kind of challenging agent for our theological reflection and religious life, cf e g Jodock (1990:377).

49. For the contributions of Ricoeur on the importance of a hermeneutics of suspicion as well as retrieval, cf e $\mathrm{g}$ White (1991:311-321).

50. As Wimbush (1993:129) argues, the "cultural worlds of readers" determine which texts are to be read, how they are to be read, what they mean, even the meaning of text itself. 


\section{Readers in Social Locations}

In the last 250 years debates about the meaning of a text have tended to dominate biblical interpretation. Such debates are related to a curious inversion which has taken place in the history of biblical interpretation. Initially, interpreters operating within relatively limited ecclesial contexts produce numerous different readings. Over time, the numbers of different social locations in which people interpreted the Bible have increased while the number of interpretive options pursued in each location have decreased (Fowl and Jones 1991:14).

It is rather obvious that all readers share one attribute, regardless of personality, culture and location: they are living bodies. ${ }^{51}$ But real readers are perhaps best identified with reference to their social location, which inevitably amounts to more than just rubbing of on their reading, as it influences not only the results of their reading, but often also their choice of methodology, and their purpose in reading. "Location is everything" is the dictum of Stephen Fowl (1995:399) when he argues for a theological reading of Scripture, since this reading exists through a reciprocal relationship with a community's faith and practice, where the latter shape and are shaped by such reading. At a broader level, and regardless of the nature or persuasion of a particular community, all readers are in material communities of some or other kind.

It is important to link real reader and social location $^{53}$ - the one which does not exist without the other - since a focus on social location may induce the fallacious notion that it is static in spatial and temporal sense, and that social location therefore assumes a static, ontological status. Accepting the multiplex and changing nature of self, means that a person must be understood in a flexible and but also context-dependent way. A reader is a real person, with a flesh-and-blood body which functions as a hermeneutical category, embedded as a body is in subjectivity, history, culture and difference. In fact, "[w]e approach the text with our lives", and with everything our lives entail which are often "no great things worth mentioning" (Pereira 2002:235-236). The ordinariness of life is so often what defines people, what makes them what and who they are, so that people's daily lives offer not only immense diversity but also huge richness.

A hermeneutics predisposed towards real readers therefore require an awareness of, and the ability to include the politics of location when studying the encounter between reader and text.

[A] politics of location, as distinct from a politics of identity, ${ }^{54}$ attempts to acknowledge both the complexity and mutability of each person's relation to world society by carefully

51. Perhaps part of the academy's uneasiness with the real reader is his/er bodily nature, particularly as in the Christian tradition people generally are "constitutionally uneasy about being bodily" (Dunnill 2002:110). But this is a topic for another discussion.

52. Among NT scholars, Bultmann was among the first to raise the importance of the social location of readers with his emphasis on the impossibility of presuppositionless exegesis (cf Vanhoozer 1995:305); Levison and Pope-Levison (1995:329) also refers to Bultmann in their claim that "no interpreter can understand any text without prejudgements formed from his or her own context" (emphasis added).

53. The social context-dependent nature of reflexive constructions of the self is denoted by the use of the first person pronoun.: "The construction of the dialogical self is a corrective to the belief that self and society are discrete conceptions" (Sarbin's foreword to Hermans and Kempen 1993:xiv). "An important implication of the dialogical or conversational view is that the self is not an intraphysic but a relational phenomenon, that typically transcends the boundaries between the 'inside' and the 'outside"' (Hermans and Kempen 1993:xxi).

54. Instead of focussing on a politics of identity, a politics of location would be more adequate for our postmodern day, where a "fluid, shifting, and generally context-dependent" view of identity makes more sense (Tolbert 1995:305ff). 
analyzing the "facts of blood and bread" and also the highly contextual nature in which those "facts" are lived out in daily experience (Tolbert 1995:314).

Location is more important than an "essentialist" identity and is dependent on "facts of blood" - social, personal and familial alignments - and "facts of bread" - national, economic and political matters. Whereas "'facts of blood' constitute the shifting complexity of the one who speaks", it is to the "facts of bread" that belong the power to situate where one speaks, the grounds for authority, national and institutional context, economic and educational status that shape each utterance we make and often determine who will listen to what we say and who will not (Tolbert 1995:311-312).

The implications of this distinction are even more evident in a situation of oppression. Within a politics of location, "solidarity may be founded upon the affective experience of oppression rather than solely upon narrow definitions of 'essence' or particular collective circumstances". The emphasis is therefore not on solidarity through the recognition and/or repetition of similar identity but through the shared longing for a alternative reality. Such solidarity with the marginalised of society and political coalitions can therefore be decided on choice, and not as prearranged coherence in need of duplication ${ }^{55}$ (Tolbert 1995:313-314).

Since a reader's social location also forms the locus of reading, it follows that attention to real readers also require attention to their social locations. The social location or situation in which a reader find him/herself influences the way a reader reads, defines the purpose of reading and determines the relevancy and appropriateness of both text and interpretation. Real readers are important not only because they are co-producers of meaning. Real readers engage texts from their own contexts for specific reasons, they take texts serious, and are socially and textually engaged. Connecting reader and social location on the other hand allows for engaging the reader as a living being, contiguous with an equally animate social location characterised by dynamism and change as all social locations are, today in particular. ${ }^{56}$

\subsection{Meaning, Method and Readers}

Hans George [sic] Gadamer has identified the limitation of hermeneutical method, in reminding us that method is incapable of revealing new truth; it only renders explicit the kind of truth already implicit in the method (Villa-Vicencio 1981:15).

Considering the role of the reader in the interpretive process and especially his/er contribution to meaning, requires attention to and accounting for the guiding role played by methodologies. This is not meant to imply that emphasis on the contribution of the reader in the production of meaning require a specific reader-respons $\mathrm{s}^{57}$ or reception theory to be used. Rather, the simple but important point is that methods to a large extent provide for and allocate a certain role to readers. ${ }^{58}$ For example, when the historical-critical method is used in interpreting a text, the method as such does not allow for regarding the reader's contribution to

55. Unlike a politics of essentialist identity, "the other" is within a politics of location identified as people "unworthy" through actions or thoughts, not through the absence of a small selection of traits, such as, male, white, wealthy, First World, physically sound, heterosexual, Christian, middle-and upper class (Tolbert 1995:313-315).

56. The influence of issues such as marginality, diaspora and others on interpretive communities has to be discussed elsewhere.

57. In any case, "Reader-Response, then, serves as an umbrella term for a variety of positions held together only by their concern with what goes on in the mind of the reader when he or she picks up and peruses a book" (Winter 1995:529).

58. Naturally, this refers to those who consciously employ a specific method with which to read or interpret Scripture. Cf Villa-Vicencio (1981:16) who claims that most (read: systematic) theologians fall outside this category. 
the process, as meaning is seen to be locked up in the historical background of the text, or the author's intention, and so forth. Also, using a structuralist approach would locate meaning in the "deep-structures" embedded in the text and disallows the value of interpreters' skill and (ideological) interest in locating (=constructing) those structures in the text, to the advantage or detriment of the text's meaning. ${ }^{59}$ The danger of decontextualised and depersonalised theory presents itself!

The major problem with reader-unfriendly theories is their failure to reckon with the reader's contribution to meaning, even within a traditional historical-critical or grammaticohistorical approach where training, presuppositions and aims of readers can decisively influence their interpretation. Perhaps one should substitute the "even" with "especially" because in those theories the reader's training, presuppositions and ideology goes largely, if not completely, unaccounted for. But these methodologies in fact do not eliminate the reader's contribution to the formation of meaning in a direct way, as they merely disallow proper recognition of the reader's inevitable contribution in the process of producing meaning.

Advancing another step may introduce a vicious circle: readers are not only the casualties of the perimeters of their selected methodologies, but readers probably choose certain methodological approaches because of their interpretive aims and goals. "Depending upon what the aims might be, a text may mean different things to different readers at different times... These methods in turn influence the way in which interpreters perceive and use the data of the text" (Tate 1991:173-174). But, furthermore, "[e]very method is in turn anchored to a set of presuppositions that determine the questions to be put to the text; and the answers are those expected in advance" (Tate 1991:173). ${ }^{60}$ The notion that method determines what kind of data can be investigated and be considered relevant beforehand, is underlined by Gadamer's argument that method not only "attains but creates its object"61 (Schneiders 1991:23). And finally then,

[t]hese interpretive approaches deeply affect how persons understand and come to their beliefs and practices and constitute the very rationality with which people approach, articulate, and explain their identity in relation to their particular cultural and political situations (Schüssler Fiorenza 1991:118).

In short, methods are as much limited as characterised by the social location of their origin and development, eliciting the results they were developed to generate, and with such results portraying as much about the method and its users, as about the text.

The acclaimed innocence of those who read the New Testament without method or a specific approach, ${ }^{62}$ fails to account for the common observation and growing acceptance that

59. Cf Segovia's broad typology of the major hermeneutical approaches employed in biblical studies (Segovia 1995a:1-32).

60. Cf Goldingay's argument that differences on methodology between scholars rests on their different assumptions and beliefs (1993:8). Schüssler Fiorenza (1991:118-119) contends that many controversies and disagreements exist in interpretation not only because of people's different beliefs and values but also because of their different interpretive approaches to beliefs, values and practices. If these beliefs and values are left unrecognised and unaccounted for, there is little hope of constructive engagement and debate regarding methodology, the use of method, or the meaning (interpretive interests) readers insist to derive from their encounters with texts.

61. And cf Fish's dictum regarding readers and their readings: "the sentence that seems to need no interpretation is already the product of one" (Pike 2003:40).

62. The reaction of those who deny the reader any role in the production of meaning is understandable within the context of the erstwhile - and to a certain extent today still - pervasive archeological notion of meaning. Meaning is excavated from texts and the more exegetical work that is done and with the necessary commitment of the excavator, the end result is assured in the form of the meaning of the text. However, does the absolute denial of any role "played by" or ascribed to the text in the interpretive process not sound equally "fantastic"? 
no human being exists neutrally, or objectively unbiased. ${ }^{63}$ In fact, the assumptions and presuppositions that are subsequently espoused in the acclaimed neutral reading very often clearly illustrate its antecedent line of thought. ${ }^{64}$ Not only does all people live according to their understanding but this understanding like "(a)ll observation is theory laden" (HamertonKelly 1992:1). ${ }^{65}$

The tension between positions aligned with or accused of objectivism and those of relativism, also requires a few words before concluding the argument.

\subsection{Beyond Objectivist and Relativist Readings: \\ Relationality, or the Dialogical Element}

Questions about the active, creative and often overpowering role of readers in relation to meaning and methods, cannot avoid to deal with the debate which has been raging for many a decade, regarding the relationship between reader and text. Even if all reading of texts is negotiated, managed through interrupted access, is meaning in the text or outside, waiting already in a social location, and activated by readers? $?^{66}$

Is it possible to escape interpretive anarchy if the choice is to avoid one, single, fixed and authentic meaning ${ }^{67}$ through allowing diverse, pluralist, individual and communal readings with (more or less) the same validity; in short, is relativism to replace objectivism? ${ }^{68}$ Should it be accepted that ambiguity and polyvalency are the price to be paid for enlisting the involvement of the reader in making sense of texts (Thiselton 1999:153), or are these not necessarily preconditions for reader involvement in textual hermeneutics (so Pike 2003:42)? With scholars at various ends of the spectrum accusing the other side of either objectivism or subjectivism, often as though the accusation alone is enough to clinch the argument, the impasse is entrenched and the quest for meaning not advanced at all.

An emphasis on the subjectivity, the situatedness of reading runs the risk of being perceived as mere subjectivism, bowing to the whims, fancies, sentimentalities and ultimately

63. Human life is hermeneutical by nature, cf Schneiders (1991:158, quoting Gadamer) who refers apart from the epistemological sense of understanding, to "a more fundamental ontological sense of understanding as the characteristic mode of being of the human existent". Eagleton notes the ideological implications of renouncing method (1983:198). Cf Goldingay (1995:7).

64. Eagleton (1983:198) refers to a "stubborn ... latent structure of assumptions" which underlies the so-called method-less literary interpretation.

65. Cf Greenstein (1986:78,90 n9); Draper (1991:236) on the "general agreement in the scientific community that 'all data are theory laden""; and, West (1991:11-12) on the demise of the Enlightenment's "objective observer". The next step is to reckon with the fact that all theory is value-laden, because "All forms of theorizing make selective judgements about the significance of particular observations" (Perkins 1993:89). Cf also the comments made by Tate (1991:173ff) on the relationship between interpretive aims and choice of interpretive method, the relationship between interpretive method and perception and use of the textual data, and the relationship between interpretive method and presuppositions regarding the text - all three relationships effectively establishing an interpretive circle.

66. In the case of the latter, is it then still proper or even possible to speak of misinterpretation or misreading of texts? Misinterpretation is not a mere innocuous byproduct created by inattentive readers otherwise disposed, exercising their right to generate meaning without textual constraints, in politically unstable or unhealthy situations, or in fact, anywhere where gender, ethnic or other hierarchies hold sway. In SA it is difficult to forget that the Bible and its specific interpretation were more than a foothold for almost 50 decades of formalised Apartheid, not to mention its role in the colonial enterprise on the African continent and elsewhere. It was South African Apartheid, in particular, which claimed a biblical basis for its operating environment and policies (Combrink 1986:211-234; cf Villa Vicencio 1981).

67. Is it fair to contend that this is always the result of moralism and dogmatism? (so Clines 1997:17).

68. "[T] he basic conviction that there is or must be some permanent, ahistorical matrix or framework to which we can ultimately appeal in dtermining the nature of rationality, knowledge, truth, reality, goodness, rightness" (Bernstein 1983:8). 
irrelevancies of particular readers, a run-away hermeneutical train speeding towards the imminent disaster of oblivion - an effort thus rather to be avoided. In the academy, in particular, readerly approaches are often viewed with suspicion for its apparent inability to appropriate adjectives such as objective, scientific, rigorous, rational for its endeavours. ${ }^{69}$ Thiselton (1992:611) argues for retaining the dialectical relationship or tension between the "general and the particular, the universal and the contingent" as this is the dialectic from which hermeneutics emerges. This tension can be collapsed in two ways:

Objectivism and a pre-occupation with wholly "scientific" deductive and inductive generalizations about texts collapses the tension into a scientific, positivist, or formalistdoctrinal, system. Contextual relativism, social pragmatism, and deconstructionism, collapses the tension into a socio-contingent, fluid, life-world, in which horizons constantly shift simply in accordance with the flow of life as it is.

Given the slide towards a postmodern approach in the academy and to some extent in society, objections against objectivism are probably more often heard, but it is equally important to move beyond subjectivism or relativism as well. As alternative relation-ality has been suggested (Bernstein 1983: esp 223-231), that is, to rediscover the dialogical element of selfhood, as the measure with which to transcend both the predicaments of objectivism and relativism. ${ }^{70}$ In like manner, psychologists Hermans and Kempen (1993) argue for a dialogical self where meaning is established as movement, between individual and community: ${ }^{71}$ to retain the relative while avoiding relativism. The self is a social phenomenon and must be studied in close relationship with society. The way the self functions depends largely on the institutions that play a central role in society (Mead, referred to in Hermans and Kempen 1993:xxii). The social self ${ }^{72}$ illustrates the multiplicity of referents for the first person, the "I", highlighting that the social self consists of a number of roles.

Are we beyond objectivism and relativism, or moving there? A short answer is not possible, and it cannot be argued here in any great detail, but our efforts should be towards the development of dialogical communities "in which dialogue, conversation, phronēsis, practical discourse, and judgement are concretely embodied in our everyday practices", amidst the powerful, constraining forces "distorting, undermining and systematically blocking" such efforts (Bernstein 1983:229-230).

69. However, as pointed out above, Segovia's appropriation of "cultural studies" - intercultural criticism - in biblical hermeneutics is a viable and credible methodology for accounting for both readers and their social locations, cutting broader and wider than Reception and Reader-Response approaches. A second example is autobiographical criticism which not only breaks with the depersonalised and decontextualised nature of biblical criticism, but also reactivates the personal dimension of reading and provides a forum where the reasons, emotional, cognitive and otherwise, why a text was found interesting can be discussed (cf Winter 1995:546).

70. Bernstein (1983:11-12) distingusihes between subjectivism (matters of personal taste, opinion or bias) and relativism (concerning a denial of any "higher appeal", allowing appeals to an irreducible pluralism of schemes, paradigms and practices only). Cf Jewett's argument on Pauline thought which would allow for a measured relativity, allowing for "reflected" as well as "perfect knowledge" (1994:98-111).

71. In essence, Hermans and Kempen adopts (and adapts) Bahktin's notion of polyphony, or multiple voices.

72. The Cartesian notion of self forms the basis of certainty but leaves "a self of reason completely purged of body and feeling, as self without shadows, a self totally transparent to itself, totally knowing of itself, totally self-possessed, totally certain of itself' (Levin). From early on (cf Vico in the 17th century) Descartes' failure to account for historical knowledge - the construction and reconstruction - in human awareness is criticised (Hermans and Kempen 1993:1-7). Cf also George (1996:217-226) on identity as a relational concept in the Christian tradition. 


\section{Conclusion}

[T] exts themselves cannot speak and have nothing to say; without readers, the Bible text, like all texts, is mute (Clines 1997:16).

Bible reading and interpretation is no neutral, disinterested enterprise, at least for the majority of users of the Book. The failure to respect the partiality, the otherness, of Bible reading can lead to accusations that only those who has no interest in the text except for a narrow individualist-personal or academic-personal interest can afford to concentrate on the Bible as only "another book", and benefit from it. Not wishing to perpetuate the often debilitating divide between real readers of the Bible in- and outside of the academy, it has to be kept in mind that the majority of Bible-readers does not have the privilege which is often ensconced in a comfortable professional-theologian or academic settings, where the need to deal seriously with what is considered weighty matters by most Bible readers, often depends on the individual him/herself in a particular social location. If texts need readers to make sense as Clines rightly points out, does readers not also need texts in order to be able to read?

My essay focused on the need to acknowledge the reader as a vital component in the hermeneutical process, since readers do not simply retrieve but effectively if unknowingly contribute to textual meaning. My argument is not for or against a particular method, although the implications of my argument do put certain approaches out of contention; moreover, the choice is no longer, if it ever was, between either the (relative) importance of methodologies, or the importance of the reader's contribution to biblical interpretation. Rather, the pervasiveness and importance of critical method should be acknowledged and then not only in the academy, but also as it is forwarded on through church, parents, school teachers, friends, societies and the like, as well as readerly contributions, regardless of level of training, academic learning, and so on. In the end, what also has to be acknowledged and brought into play is to accept that when readers read from where they are, when their social locations' contributions are recognised, texts and meanings are deconstructed and reconstructed. Amidst remaining ambiguities and diverse methodologies, the text then also becomes a tool of liberation, in the sense of stimulating alternative interpretations and so invalidating attempts to control the text and its use (Pereira 2002:238).

The debate on the role of the reader in establishing and shaping meaning is conducted in a context dominated by a concern for historically reconstructing the original setting (Thiselton 1999:158), and the discussion gets stuck too often in issues about historiography ${ }^{73}$ With the focus on readers, issues of power and relationships can be fore-grounded, and ideology, politics and social locations in general inevitably have to be factored into all readings in the sense that their presence and influence have to be accounted for, as the bodily and material nature of our existence and its implications for the reading process have to be dealt with. Taking up the challenge to read as real readers, and to listen to the readings of real readers, amounts to more than just a shift in hermeneutical gear, and requires a different epistemology and the development of a broader repertoire of skills.

73. Under the influence of the New Historicism (Hens-Piazza 2002; Lategan 2003), some historiographers are gradually accepting the nature of their task to be one of "sense-making" or constructing, rather than "questing" or establishing brute historical facts. 


\section{BIBLIOGRAPHY}

Adam, AKM 1995. What Is Postmodern Biblical Criticism. Guides to Biblical Scholarship. Minneapolis: Fortress.

Aichele, G 1993. Reading beyond meaning. Postmodern Culture 3(3): 1-15.

(http://jefferson.village.virginia.edu/pmc/text_only/issue.593/aichele.593)

Barr, DL 1995. New Testament Story. An introduction. $2^{\text {nd }}$ ed. Belmont: Wadsworth.

Berg, TF 1989. Reading in/to Mark. Semeia 48: 187-206.

Bernstein, RJ 1983. Beyond objectivism and relativism: Science, hermeneutics and practice. Oxford: Basil Blackwell.

Bohnen, J 2000. Judas, Jesus and Table Manners. An Intertextual Reading of John 13:26, Matthew 25:23 and Sirach 31:12-32:13. The South African Baptist Journal of Theology 9: 75-104.

Bray, G 1996. Biblical Interpretation: Past \& Present. Leicester: Apollos.

Brett, MG 1990. Four or five things to do with texts. A taxonomy of interpretative interests. In eds. Clines, DJA, Fowl, SE and Porter, SE, 357-78.

Clines, DJA 1993. Possibilities and priorities of biblical interpretation: An international perspective. Biblical Interpretation 1(1): 67-87.

Clines, DJA 1997. The Bible in the modern world. Sheffield: Sheffield Academic Press.

Clines, DJA SE Fowl and Porter, SE, eds. 1990. The Bible in three dimensions. Essays in celebration of forty years of Biblical Studies in the University of Sheffield. Sheffield: JSOT Press.

Combrink, HJB 1986. Perspektiewe uit die Skrif. In Die NG Kerk en Apartheid, ed. Kinghorn, J, 211-234. Johannesburg: MacMillan.

Cormie, L 1991. Revolutions in Reading the Bible. In The Bible and the Politics of Exegesis. Essays in Honor of Norman K Gottwald on His Sixty-Fifth Birthday, eds. Jobling, D, Day, PL and Sheppard, GT,173-93. Cleveland: Pilgrim.

Draper, J 1991. "For the Kingdom is inside of you and it is outside of you": Contextual exegesis in South Africa. In Text and Interpretation. New Approaches in the Criticism of the New Testament, eds. Hartin, P and Petzer, J, 235-57. Leiden: EJ Brill.

Dunnill, J 2002. Being a Body. Theology 105(824): 110-7.

Eagleton, T 1983. Literary Theory. An Introduction. Oxford: Basil Blackwell.

Fowl, SE. 1990. The ethics of interpretation or what's left over after the elimination of meaning. In eds. Clines, DJA, Fowl, SE, and Porter, SE, 379-98. Sheffield: JSOT Press.

Fowl, SE 1995. The New Testament, Theology, and Ethics. In ed. Green, JB, 394-410.

Fowl, SE and Jones, LG 1991. Reading in Communion. Scripture and Ethics in Christian Life. Grand Rapids: Eerdmans.

George, KM 1996. Cross-cultural interpretation: Some paradigms from the Early Church. International Review of Mission 85(337): 217-26.

Goldingay, J 1993. How Far Do Readers Make Sense? Interpreting Biblical Narrative. Themelios 18(2): 5-10.

Goldingay, J 1995. Models for Interpretation of Scripture. Grand Rapids, Carlisle: Eerdmans, Paternoster.

Green, JB ed. 1995. Hearing the New Testament. Strategies for Interpretation. Grand Rapids, Carlisle: Eerdmans, Paternoster.

Greenstein, EL 1986. Theory and Argument in Biblical Criticism. Hebrew Annual Review 10: 77-93. 
Hamerton-Kelly, RG 1992. Sacred Violence. Paul's Hermeneutic of the Cross. Minneapolis: Fortress Press.

Harrisville, RA 1995. A Critique of Current Biblical Criticism. Word \& World 15(2): 206-13.

Hens-Piazza, G 2002. The New Historicism. Guides to biblical scholarship; Old Testament Series. Minneapolis: Fortress.

Hermans, HJM and Kempen, HJG 1993. The dialogical self. Meaning as movement. San Diego: Academic Press.

Jeffrey, DL 1996. People of the Book. Christian identity and literary culture. Grand Rapids: Eerdmans.

Jewett, R 1994. Paul the Apostle to America: Cultural Trends and Pauline Scholarship. Louisville: Westminster John Knox.

Jodock, D 1990. The Reciprocity between Scripture and Theology. The role of Scripture in contemporary theological reflection. Interpretation 44(4): 369-382.

Lategan, BC 1994. Current issues in the hermeneutical debate. Neotestamentica 18: 1-17.

Lategan, BC 2003. Questing or sense-making? Some thoughts on the nature of historiography. Unpublished paper.

Levison, JR and Pope-Levison, P 1995. Global perspectives on New Testament interpretation. In ed. Green, JB, 329-348.

Long, TMS 1994. A real reader reading Revelation. Neotestamentica 28(2): 395-411.

Meeks, WA 1986. A Hermeneutics of social embodiment. Harvard Theological Review 79 (1-3): 176-86.

Moore, SD 1989. Literary criticism and the Gospels. New Haven: Yale University Press.

Morgan, R and Barton, J 1988. Biblical Interpretation. Oxford Bible Series. Oxford: Oxford University Press.

Pereira, NC 2002. The body as hermeneutical category. Ecumenical Review 54(3): 235-239.

Perkins, P 1993. Canon, paradigms and progress? Reflections on the essays by Rendtorff, Sugirtharajah and Clines. Biblical Interpretation 1(1): 88-95.

Petersen, NR 1978. Literary criticism for New Testament critics. Guides to biblical scholarship; New Testament series. Philadelphia: Fortress.

Pike, MA 2003. The Bible and the reader's response. Journal of Education \& Christian belief $7(1): 37-51$.

Poirier, JC 2000. Some detracting considerations for Reader-Response theory. Catholic Biblical Quarterly 62(2): 250-63.

Pregeant, R 1995. Engaging the New Testament. An interdisciplinary introduction. Minneapolis: Fortress.

Punt, J 1998a. "My Kingdom for a method": South African New Testament scholarship and methodological preoccupation. Neotestamentica 32(1): 135-160.

Punt, J 1998b. New Testament interpretation, interpretive interests, and ideology: Methodological deficits amidst South African methodolomania. Scriptura 65(2): 123152.

Schneiders, SM 1991. The revelatory text. Interpreting the New Testament as sacred Scripture. San Francisco: HarperSanFrancisco.

Schüssler Fiorenza, F 1991. The Crisis of Hermeneutics and Christian Theology. In Theology at the end of Modernity. Essays in honor of Gordon D Kaufman, ed. Davaney, SG, 117-40. Philadelphia: Trinity Press International.

Segovia, FF 1995a. "And they began to speak in other tongues": Competing modes of discourse in contemporary biblical criticism. In Reading from this place. Vol. 1: Social location 
and biblical interpretation in the United States, eds. Segovia, FF and Tolbert, MA, 1-32. Minneapolis: Fortress.

Segovia, FF 1995b. The Text as Other. Towards a Hispanic American Hermeneutic. In Text \& Experience. Towards a Cultural Exegesis of the Bible, ed. Smith-Christopher, D 276298. Biblical Seminar, vol. 35. Sheffield: Sheffield Academic Press.

Segovia, FF 2000a. Decolonizing biblical studies. A view from the margins. Maryknoll: Orbis.

Segovia, FF 2000b. Reading-across: Intertextual criticism and textual posture. In Interpreting beyond borders, ed. Segovia, FF, 59-83. The Bible and Postcolonialism, vol. 3. Sheffield: Sheffield Academic Press.

Segovia, FF and Tolbert, MA, eds. 1995. Reading from this place. Vol.1: Social location and biblical interpretation in the United States. Minneapolis: Fortress.

Siker, JS 1993. Review of Fowl, SE and Jones, LG. Reading in Communion. Scripture and Ethics in Christian Life. CBQ 53: 150-152.

Smit, DJ 1998. Biblical hermeneutics: the 20th Century. In Initiation into theology. The rich variety of theology and hermeneutics, eds. Maimela, S and König, A, 297-317. Pretoria: Van Schaik.

Tate, WR 1991. Biblical interpretation. An integrated approach. Peabody: Hendrickson.

The Bible and Culture Collective 1995. The Postmodern Bible. New Haven and London: Yale University Press.

Thiselton, AC 1992. New horizons in hermeneutics: The theory and practice of transforming biblical reading. London, Grand Rapids, Carlisle: HarperCollins, Zondervan, Paternoster.

Thiselton, AC 1999. Communicative action and promise in interdisciplinary, biblical and theological hermeneutics. In The promise of hermeneutics, Lundin, R, Walhout, C and Thiselton, AC, 133-239. Grand Rapids: Eerdmans.

Tolbert, MA 1995. Afterwords. The politics and poetics of location. In eds. Segovia, FF and Tolbert, MA, 305-317.

Vanhoozer, KJ 1995. The reader in New Testament interpretation. In ed. Green, JB, 301-28.

Villa-Vicencio, C 1981. The Use of Scripture in Theology. Towards a contextual hermeneutic. Journal of Theology for Southern Africa 37: 3-22.

Vorster, WS 1988. Towards a Post-Critical paradigm: Progress in New Testament scholarship? In Paradigms and progress in theology, eds. Mouton, J, Van Aarde, AG and Vorster, WS, 31-48. Pretoria: HSRC.

White, E 1991. Between suspicion and hope: Paul Ricoeur's vital hermeneutic. Journal of Literature and Theology 5(3): 311-321.

Wimbush, VL 1993. Reading texts through worlds, worlds through texts. Semeia 62: 129-139.

West, GO 1991. Biblical hermeneutics of liberation. Modes of reading the Bible in the South African context. Cluster Monograph Series, vol. 1. Pietermaritzburg: Cluster Publications.

Winter, TR 1995. Reader-Response under review: Art, game, or science? Style 29(4): 529-549. 